\title{
(2) OPEN ACCESS \\ Sarah Orne Jewett's depictions of women in a changing medical profession: Nan Prince and Almira Todd
}

\author{
Catherine Hand ${ }^{1,2}$
}

\begin{abstract}
${ }^{1}$ Arkansas College of Osteopathic Medicine, Fort Smith, Arkansas, USA ${ }^{2}$ English, Wichita State University, Wichita, Kansas, USA
\end{abstract}

\section{Correspondence to} Catherine Hand, Arkansas College of Osteopathic Medicine, Fort Smith, AR 72916 , USA; chand@arcomedu.org

Accepted 7 August 2019 Published Online First 5 October 2019

\section{Check for updates}

(c) Author(s) (or their employer(s)) 2020. Re-use permitted under CC BY-NC. No commercial re-use. See rights and permissions. Published by BMJ.

To cite: Hand C Med Humanit 2020;46:e5.

\section{ABSTRACT}

Sarah Orne Jewett, who lived from 1849 to 1909, witnessed a revolution in medicine that led to the formation of the medical profession as it is recognised today. By comparing two of the author's works, one written at the outset of her career and the other written much later, this paper discusses how Jewett's views about women's role in medicine changed and developed. In the first novel, $A$ Country Doctor, a young Jewett celebrates the new-found power of scientific medicine in the period directly after germ theory was widely adopted. The author depicts a female physician as a pioneer bravely breaking into a male-dominated field. Later, in The Country of the Pointed Firs, Jewett's depiction of a female medical practitioner is much more nuanced - the matured writer's views are accompanied by discrete but deep-seated criticisms of medical ideology as she saw it developing. The comparison of these novels gives us insight into Jewett's world, and leaves questions for readers today. Most importantly, how should women today approach traditional medicine given the discipline's deeply misogynist roots? Jewett's unique perspectives serve as a catalyst for this discussion.

Sarah Orne Jewett's depictions of female medical practitioners in A Country Doctor and The Country of the Pointed Firs reflect the extensive changes occurring in medical practice in the USA during the latter half of the nineteenth century and the beginning of the twentieth century. The author's understanding of natural, integrative and psychological medicine foreshadowed developments even in the twenty-first century. Jewett employed her first-hand knowledge of the medical profession in the late 1800s to draw the characters of Nan Prince, Dr Leslie and Almira Todd. In the semiautobiographical work A Country Doctor published in 1884, the central character, Nan Prince, is a young woman studying to be a physician. In Jewett's more famous later work, The Country of the Pointed Firs, published in 1896, Almira Todd works as her community's herbal apothecary. Female practitioners, Almira and Nan, give us a glimpse of traditional medical practices and of a profession in transition; their work is complicated by rapidly changing professional and academic expectations, by the changing roles of women in medicine and by the effects of urbanisation on medical practices.

In the 12 years between the creation of Jewett's characters, Nan and Almira, Jewett's ideas about the direction medicine should take broadened remarkably. Jewett became attuned to integrative, holistic and community-based medical needs in ways embraced by few-if any-of her peers. In her early work, A Country Doctor, Jewett's portrait of Nan demonstrates the author's enthusiasm for the advances being made by an emerging evidencebased medical system. Later, in The Country of the Pointed Firs, Jewett's enthusiasm would be tempered by the understanding that this new system must not be used indiscriminately. To be an exceptional practitioner, and indeed, to harness the full power of this new medical science, Jewett saw that it was necessary to step back, to respect certain aspects of traditional wisdom. Jewett's portrait of Almira shows how the author considered it necessary to think creatively and to view the patient in his or her unique environment in order to fashion more informed and tailored medical care.

Today, as an American medical student, I am surrounded by conversations about the future of medicine. The question arises, how can our medical community-founded on systems-based pathologydriven ideas-approach unprecedented levels of chronic and preventable disease. The bulk of these problems, for example, diabetes and heart disease, are lifestyle-based and of multifactorial aetiologies: mental, social, economic and cultural problems contribute. Nearly 130 years ago, Jewett's nuanced approach to medicine in The Country of the Pointed Firs, grappled with ideas highly relevant to these contemporary problems.

Jewett's interest in medicine can be traced to her family background. A Country Doctor is loosely based on Jewett's relationship with her father who practised as a physician in Maine. Like Nan with her guardian Dr Leslie, Jewett would often accompany her father on house calls in the country. Jewett's father was also a medical professor, so Jewett had exposure to the profession's latest theories and organisational efforts. Jewett's proximity to her father's work and her own studies allowed her to witness important changes in the American medical profession.

Jewett, who lived from 1849 to $1909^{1}$, witnessed a revolution in medicine that led to the formation of the medical profession as it is recognised today. Shortly after Jewett's birth, the Civil War ushered in a period of profound changes in medical theory and methods in the USA; medicine became a more codified and respected profession as regulatory bodies were established, germ theory was widely adopted, surgical risk was reduced and governments commissioned public health reforms. 
Prior to these changes there were many disparate forms of medicine and quackery in the USA. From the pre-Revolutionary Period to the Civil War, unregulated practices competed for patients. Midwifery, Native American medicine, herbal medicine, spiritual healing, homoeopathy, heroic medicine, countless forms of quackery, and varying iterations of medical fads from Europe were offered to American patients. Though there was great variety, nearly all practice lacked theoretical and professional cohesion.

The urgent medical needs of the Civil War brought increased codification and communication though the organisation of military hospitals. This catalysed the widespread American acceptance of germ theory, sanitation practices and diagnostic laboratory methods developed by European physicians. According to historians Shauna Devine and Elaine Breslaw, the Civil War marked the beginning of the consolidation of medical theories and organisations in the USA that would culminate in the ascendency of regulatory organisations like the American Medical Association and the establishment of board examinations. ${ }^{2}$ The turn of the century marked the beginning of the overwhelming pre-eminence of orthodox Western practice as it continues to the present day.

The resulting improvements in medical care and sanitation measurably improved human health despite the period's increasing urbanisation. Beginning in 1900, death registries allowed the government to publish an annual report on statistical trends in all-cause mortality. From 1900 infectious disease mortality dropped by nearly three per cent every year until 1937. Between 1938 and 1952 the drop was even more dramatic at about eight per cent per year. ${ }^{3}$

A Country Doctor reflects Jewett's acute awareness of the changing state of medicine during her lifetime. In the novel Dr Leslie is a renowned physician who, despite his age and duties as a rural practitioner, keeps up with the latest medical innovations and conversations. In one scene Dr Leslie is shown reading and critiquing a 'stout French medical work of high renown'. The scholarly doctor uses the relative tranquillity of rural life to advance his studies: 'The leisure he often had at certain seasons of the year was spent in the studies which always delighted him, and little by little he gained great repute among his professional brethren'.

Dr Leslie encourages his ward Nan Prince to study medicine despite her gender. Nan's story lends insight into the birth of modern medical practices, and the difficulties faced by female physicians in the late nineteenth and early twentieth centuries. During her adolescence, Nan struggles inwardly with her decision to pursue medicine because she is concerned by her society's disapproval. Jewett described Nan's struggle:

[Nan] tried to fancy herself in sympathy with the conventional world of school and of the everyday ideas of society. And yet her inward sympathy with a doctor's and a surgeon's work grew stronger and stronger, though she dismissed reluctantly the possibility of following her bent in any formal way, since, after all, her world had seemed to forbid it. ${ }^{6}$

After long deliberation Nan disregards the prejudices of her society to pursue her vocation as a physician: 'People might laugh or object. Nothing should turn her aside. ${ }^{77}$

During Nan's medical studies she fully recognises the double standard of her society. Jewett described Nan's difficulties as a young woman in medical school, stating, 'If a young man plans the same course, everything conspires to help him and forward him, and the very fact of his having chosen one of the learnt professions gives him a certain social preeminence and dignity. But in the days of Nan's student life it was just the reverse. ${ }^{8}$ Nan recognises that for a young woman, the coveted medical diploma, 'was only a formal seal of disapproval in most persons' eyes'.

Despite obstacles and oppression, female physicians like Nan found acceptance and success 'through hard work and much study'. ${ }^{10}$ Despite high barriers to entrance into American and European medical schools, women used the increasing rigour of medical education to their advantage. Commentator Deborah Levine writes that women used 'the language of professionalisation and the standardisation of credentials to argue for their legitimacy with in the American medical profession'. ${ }^{11}$ Jewett attributes her character's success to this attitude as well to her intuition and empathy. Nan's attitude towards her work is characterised by sympathy for the suffering she witnesses:

Nothing had seemed to rouse [Nan's] ambition so greatly as her experiences at the children's hospitals the winter before. Now, this weak little creature seemed to be pleading in the name of a great army of sick children, that Nan would not desert their cause; that she would go on, as she had promised them, with her search for ways that should restore their vigour. ${ }^{12}$

Successful female physicians in the early twentieth century expressed similar sentiments. Paediatric resident, Martha May Eliot wrote to her parents,

I lost my second child to diphtheria last night - a cunning little girl of five...It is fearful when you have to stand by and know there is nothing more you can do - I hope I shall get a number of diphtheria cases so as to have as much experience with them as possible. ${ }^{13}$

In the novel, both Nan and Dr Leslie recognise that formal medical education had become essential for gaining respect in the field. Jewett wrote 'without any discussion it was decided that [Nan] must enter the medical school to go through with its course of instruction formally, and receive its authority to practice her profession'. ${ }^{14}$ Nan and Dr Leslie's attitudes about formal medical education demonstrate the importance of medicine's increasing standardisation and professionalisation. Despite the rigours of medical studies, the idea of a positive future professional reputation drives Nan to persevere. Jewett wrote, '[Nan's] later schooldays were sure to be more trying than her earlier ones, as they carried her into deeper waters of scholarship, and were more important to her future position before the public'. ${ }^{15}$ Like her mentor Dr Leslie, Nan hopes to advance her medical knowledge even after receiving her degree and, by the close of the novel, Nan is considering continuing her studies in Zurich, Switzerland.

Jewett's evident appreciation for the professionalisation of medical education and the effective application of scientific principles in A Country Doctor was timely; it came, however, with some degree of scepticism. At the time, the consolidation and codification of medical practice was universally praised by physician historians. It has only been since the last decades of the twentieth century that social historians and historians of healthcare have revealed its underbelly. ${ }^{16}$ Economic incentives, gender and racial discrimination, and the desire for personal fame underwrote some of mainstream medicine's new policies and practices. Through their benevolence and opposition to gender discrimination, Dr Leslie's attitudes, and to a lesser extent, Nan's, foreshadow these later historians.

Jewett criticised reductive, detached attitudes that sometimes accompanied the new medical standards. Through the character of Dr Leslie, she advocated for medical practice based on pathology and quantification, and on experience and a 
comprehensive, empathetic approach to human nature. A physician should be capable of addressing social and psychological ills, problems Jewett calls 'sadder ailments than the textbooks name. ${ }^{17}$ Dr Leslie calls for critical analysis to find the roots of human problems. While speaking with his colleague Dr Ferris, Dr Leslie queries rhetorically, 'If we blindly follow the medical dictators, as you call them, and spend our treatment on the effects instead of the causes, what success can we expect'. ${ }^{18}$

Medical reforms during the period sought to professionalise medicine in the eyes of the public. By supporting common pseudoscientific ideas, for example, social Darwinism, the effort to professionalise medicine contributed to discrimination against women and minorities. Medical historian Ronald L Numbers claimed that the 'negative beliefs of male physicians toward women helped to legitimise (the male) professional role'. ${ }^{19}$ Women and minorities were barred from most elite institutions while the reforms closed many institutions that accepted them. In A Country Doctor, Dr Leslie opposes this discrimination, while Nan's professional success refutes the ideological reasons for discrimination against women.

Feminist critics have argued that the discrimination against women faced by female physicians was endemic to medical theory in the early twentieth century. Literary critics like Ann Wood decried 'aggressively hostile male sexuality and superiority' in medical attitudes concerning female patients in the late nineteenth and early twentieth centuries. ${ }^{20}$ In light of discriminatory and misogynist medical ideology, the gradual acceptance of female physicians like Nan into mainstream practice was problematic. Critic Kristine Swenson claims that female physicians, 'who ran hospitals and clinics independent of men, derived their power from and subjected their patients to the same medical "science" which upheld the sexual and racial hierarchies of Victorian patriarchy'. ${ }^{21}$ Though Jewett criticises certain aspects of medicine, and Dr Leslie opposes discrimination against women, in A Country Doctor Jewett failed to recognise Nan's conflict of interest as a female doctor subscribing to a medical ideology established almost exclusively by men. Later in Jewett's career, in the novel The Country of the Pointed Firs, the author would address and attempt to resolve this conflict indirectly through the character of Almira Todd.

Jewett's intimate understanding of the period's medical context is demonstrated in A Country Doctor. When the later work The Country of the Pointed Firs is read in conjunction with A Country Doctor, Almira's character and her alternative medical work gain additional context and layers of significance. Almira is an herbal apothecary in the fictional fishing community of Dunnet Landing in rural Maine. Her character embodies a feminine medical tradition that contrasts with, and often compliments, the male-dominated model in A Country Doctor. Jewett's views of women's historical contributions to healthcare appear more nuanced in her later work. Nan's character in A Country Doctor ascribed to a male-dominated medical model with relatively little scrutiny; she is presented as a pioneer breaking into a world that is considered new to women. The apothecary, Almira, in contrast, represents a long tradition of medicine practised and shared by women. Her herbal knowledge was handed down from other women in the community and from her French neighbour Mrs Tolland. ${ }^{22}$ (Ted Eden, 1992)Historian Deborah Brunton says that traditional women healers like Almira were common across most cultures during the nineteenth century: 'Women in every culture cared for sick family members; large numbers worked as healers and midwives'. ${ }^{23}$ Jewett's presentation of Almira's female medical tradition provides a counternarrative to an increasingly autocratic and predominantly male establishment.
Throughout the nineteenth century, female practitioners were an important part of rural healthcare. Literary critic Michael Holstein says, 'Herbalism and folk healing generally had an important function in a young nation that required medical practitioners in remote areas....Midwifery and herbalism provided outlets for women with healing missions and medical services for a widespread rural population. ${ }^{24}$ Likewise, in The Country of the Pointed Firs, Jewett demonstrates the importance of traditional social and medical practices at a time when these traditions were being abandoned en masse in favour of the recently formed urban medical establishment. Despite the difficulty of travel and her advancing age, Almira works in partnership with the community's conventional physician to care for patients living in isolated areas.

While many women entered mainstream medicine during this period, primarily as nurses, ${ }^{25}$ traditional practitioners fell out of favour. In The Country of the Pointed Firs, due to rapid urbanisation, Almira's profession is dying alongside the rural culture and community that supported her work. As Almira relates the stories of dead friends from Dunnet Landing, the reader becomes aware that Almira, who is in her 60s, will die relatively soon; with her death her extensive medical knowledge will vanish.

In addition to defending traditional female involvement in healthcare, Jewett's narrative works against the tendency of mainstream medicine to get lost in scientific minutia. Despite her recognition of the exciting and powerful new world of emerging sciences in A Country Doctor, Jewett continued to develop a cohesive understanding of the human person in his or her physical, mental and social environment. Critic Josephine Donovan claims that Jewett, 'developed an animistic view, one that... erases the divide between spiritual and material, seeing the transcendent as incarnate in the physical. ${ }^{26}$ Jewett's animism is evident in The Country of the Pointed Firs and has implications for Jewett's presentation of medical practice. Her view posits that the human body and consciousness are innately and intricately tied to the ecological world. Health is, in effect, best sought through harmony with one's environment.

In addition to its association with nature, Almira's herbalism is associated with the mysterious and unknown. The text even compares her with a witch: her herbs have 'strange and pungent odours that roused a dim sense and remembrance of something in the forgotten past. Some of these might once have belonged to sacred and mystic rites and have had some occult knowledge handed with them down the centuries' ${ }^{27}$ Almira's trade, unlike Nan's, is not based on ostensibly empirical medical science. Almira's practice, like her character, works in mysterious ways. She could not, and does not try, to explain the chemical mechanisms that make her remedies work and she could not prove statistically that they do; rather, she accepts the mysterious tradition handed down to her and uses it in conjunction with her own observations. Today the efficacy of many traditional herbal medicines have been proven and are being investigated by contemporary science. Some high-quality herbal treatments are comparable to pharmaceutical treatments but with fewer, milder side effects. Scientific medicine has shown that effective herbal medicines often contain numerous active compounds with multiple synergistic effects and highly complex mechanisms. ${ }^{28}$ (R A Cooper et al., 2010) Though Almira's traditional medicine did little to advance scientific medical understanding and lacked theoretical explanations for its own efficacy, recent discoveries suggest that it would have been, by nineteenth century standards, a relatively safe and effective form of care.

Personal relationships and community are central to Jewett's exploration of health in The Country of the Pointed Firs. As Jewett's characters endure the hard lives and isolation of 
deteriorating fishing villages in Maine, the author explores how individual physical and mental wellness is inexorably linked to the health of the community at large. Almira's work as an apothecary is framed by discussions of community and by numerous presentations of mental illness in the characters of Joanna Todd, Captain Littlepage and Abby Martin.

With the loss of the shipping industry, Almira's coastal world has been depopulated-those inhabitants that are left struggle with memories of past prosperity and with a lack of direction. Captain Littlepage comments to the narrator that, 'Shipping's a terrible loss to this part o'New England from a social point o' view, ma'am'. ${ }^{29}$ For characters like Abby Martin, who imagines she is Queen Victoria's twin, the extreme isolation of a depopulated rural area exacerbates her mental illness. Almira describes a visit to Abby's isolated area, saying, "There used to be a few good families over there, but they 've died and scattered, so now (Abby is) far from neighbours. There, she really cried, she was so glad to see anybody comin'”. ${ }^{30}$ Abby's delusion seems to be a coping mechanism for her loneliness; Almira continues, "You'll be amused to hear her talk about the Queen, but I thought twice or three times as I set there 't was about all the company she 'd got'”. This and many of the novel's depictions of mental illness share the theme of isolation and delusion. Though Almira has little ability to treat the mind through her herbal pharmacopoeia, she brings much needed relief through compassionate conversation with her patients and by treating their physical ailments.

Like Nan who returns to her village after medical school instead of taking a prestigious job in Canada, Almira's healing mission lies at home. Almira is portrayed as both a physical and psychological healer for her neighbours. She shows great patience and respect for the mentally ill in ways that only another member of their own community could-she seems accustomed to their idiosyncrasies and understands their diseases in the context of region's decay. Though Almira does what she can to alleviate her patient's psychic suffering, she sympathises with her patients through an attitude of acceptance. Reflecting this attitude, The Country of the Pointed Firs has been described by critics as an elegy for Almira's dying profession, way of life, community and friends. ${ }^{31}$

Like her herbalism, the psychological aspects of Almira's work are tied to ancient spirituality. Jewett deepens the association of Almira's practice with ancient medicine and spiritual healing when she compares Almira to the sibyls and caryatids of ancient Greece. ${ }^{32}$ The term 'sibyl' aligns Almira to cathartic religious healings performed by the Delphic oracle in early Antiquity. Later in Greek culture it became the responsibility of playwrights to provide the audience with cathartic psychological and social healing through emotional experiences of pity and fear. This Classical concept was employed in psychological discourse during Jewett's lifetime to describe how narrative can lead to emotional closure and healing through the experience of repressed emotions. ${ }^{33}$

Through empathy and catharsis, Almira's recurrent role as a narrator of and a listener to others' stories brings social and psychological wholeness to the members of her community. Like Almira's herbal treatments, the physiological efficacy of spiritual, social and psychological practices are now a subject of much scientific study. Psychotherapy, mindfulness and meditation are being investigated by contemporary medicine -- benefits include improved immunity and cardiac function. ${ }^{34}$ Medical schools are emphasising empathy as a way to improve patient outcomes. ${ }^{35}$ (Frans Derksen et al., 2015)Surprisingly, even certain aspects of Jewett's animistic view have gained quantitative relevance as the field of epigenetics explores how psychosocial trauma, like the trauma experienced by the widows and sailors of Dunnet
Landing, has the ability to alter human gene methylation. ${ }^{36}$ (Rachel Yehuda et al., 2013)

In both A Country Doctor and The Country of the Pointed Firs, Jewett advocated for an approach that is balanced by both Almira's wisdom and Nan's scientific standards. Dr Leslie gestures to the importance of such balance when he says, 'the young practitioners must follow the textbooks a while until they have had enough experience to open their eyes to observe and have learnt to think for themselves. ${ }^{, 37}$ The friendly professional partnership between Almira and Dunnet Landing's physician also demonstrates a working example of this balance. Nan and Almira's practices, though dissimilar, reflect essential elements of medicine. Nan's tradition of mainstream male-dominated Western medicine values scholarship, quantifiable scientific data and standardisation. Nan's embrace of this tradition combined with Dr Leslie's sage tutelage gives her the foundation to become an effective practitioner. Though Nan challenges social and educational norms to become a female physician, she does not, however, question the nature of her curriculum or consider the possibility that the scientific discourse of medicine could contain inherent biases against women. On the other hand Almira's parallel female-dominated tradition provides an important alternative narrative-a narrative that challenges mainstream medicine in dynamic and interesting ways. Almira's character represents essential aspects of medicine that the author identified as at risk of being forgotten given the trajectory of medicine at the turn of the century. These values include the importance of community, mental health, wisdom and empathy, the importance of personal judgement on the part of the physician and the importance of qualitative measures of health to patient life. These values can be complex and highly interconnected which may partially explain why they were not easily incorporated into a codified system and why they remain difficult for the medical system to integrate today.

In an interesting twist of history, it is out of Nan's tradition of mainstream practice that medical science today is finally illuminating and slowly incorporating Almira's complex healing tradition. In the book Biosemiotic Medicine, Farzad Goli and others present medicine as a field that is in a period of transition once again. This transition echoes Jewett's maturation as a medical thinker between A Country Doctor and The Country of the Pointed Firs. Goli says that

tolerating [a] multilingual and interdisciplinary medium, after several centuries of attempts at establishing a single pure chemophysical language, is tremendously difficult for medical discourse. It seems that for explanation, clinical reasoning, and management in the systematic approach, we should prepare ourselves for a more complicated chaotic system with increasing uncertainty. ${ }^{38}$

Jewett, writing at the close of the nineteenth century, saw with intense clarity the evolution of medical science that would span the entire next century. She wrote of the advancement and contributions of women in this male-dominated field. Through Almira, the sibyl, she predicted the resurgence of natural remedies, the importance of sociology and psychology as they pertain to physiological health, and the replacement of the whole, complex human person back at the centre of medical practice. New medical problems in the late twentieth and early twenty-first centuries have led to an increased interest in the importance of the humanities to medicine and in 'alternative' and low-risk practices like herbalism and psychotherapy. The injudicious use of relatively new medical treatments can cause unforeseen problems and has given rise to resistant bacteria and unnecessarily common iatrogenic disease. ${ }^{39}$ As shown by Goli, to address 
mounting problems medicine must reassess its own understanding of the human person and how the mind and body interact with a great number of social, environmental and historical factors. Jewett's stories, by offering insight into the birth of modern medicine, can help the field address its future. A holistic medical approach, much like the one presented by Jewett in the nineteenth century, is quickly becoming a vital part of that future in the twenty-first. Perhaps the most important lesson Jewett has to teach medicine in this century is her respect for nature. Therapies that conserve the natural state should be employed whenever possible and physicians must use discretion in the use of necessary interventions that violate it. Like Dr Leslie, Nan and Almira, physicians today should strive to 'strengthen and balance the whole system, and aid nature to make the sick man well again. ${ }^{40}$

Correction notice This article has been amended since it was first published online. It was originally published without a CC-BY-NC licence. This has now been amended.

Acknowledgements I am very grateful to my institution, the Arkansas College of Osteopathic Medicine, for the grant that enabled this publication to be open-accesss.

Funding The authors have not declared a specific grant for this research from any funding agency in the public, commercial or not-for-profit sectors.

Competing interests None declared.

Patient consent for publication Not required.

Provenance and peer review Not commissioned; externally peer reviewed.

Open access This is an open access article distributed in accordance with the Creative Commons Attribution Non Commercial (CC BY-NC 4.0) license, which permits others to distribute, remix, adapt, build upon this work non-commercially, and license their derivative works on different terms, provided the original work is properly cited, appropriate credit is given, any changes made indicated, and the use is non-commercial. See: http://creativecommons.org/licenses/by-nc/4.0/.

\section{NOTES}

1. Paula Blanchard (1994), Sarah Orne Jewett: Her World and Her Work. Reading, Mass: Addison-Wesley.

2. Shauna Devine (2016), "'To Make Something Out of the Dying in This War': The Civil War and the Rise of American Medical Science," 149-163; Elaine G. Breslaw (2012). Lotions, Potions, Pills, And Magic: Healthcare In Early America, 151-185.

3. G. L. Armstrong, L. A. Conn, and R. W. Pinner (1999), "Trends in Infectious Disease Mortality in the United States During the 20th Century", 65.

4. Sarah Orne Jewett (1996), "The Foreigner, " A Country Doctor, The Country of the Pointed Firs, "The Foreigner," Novels and Stories. (New York, Library of America).

5. Jewett, $A$ Country Doctor, 75.

6. Jewett, A Country Doctor, 127.

7. Jewett, $A$ Country Doctor, 131.

8. Jewett, $A$ Country Doctor, 151.

9. Jewett, $A$ Country Doctor, 151.

10. Jewett, $A$ Country Doctor, 266

11. Deborah Levine (2016), "'I Haven't Time to Write:' Martha May Eliot and American Medical Education Reform", 724

12. Jewett, $A$ Country Doctor, 266.

13. Levine, "'I Haven't Time to Write:' Martha May Eliot and American Medical Education Reform", 726

14. Jewett, $A$ Country Doctor, 151

15. Jewett, $A$ Country Doctor, 151.

16. R. L. Numbers (1982), "The History of American Medicine: A Field in Ferment", 256.

17. Jewett, $A$ Country Doctor, 267

18. Jewett, $A$ Country Doctor, 87.

19. Numbers, "The History of American Medicine: A Field in Ferment", 256.

20. Numbers, 260

21. Kristine Swenson (2005), Medical Women And Victorian Fiction, (Columbia: University of Missouri Press), 9, 47

22. Jewett, "The Foreigner," 540; Ted Eden (1992), A Jewett pharmacopoeia, vol. 3, 4: Colby quarterly 28. http://digitalcommons.colby.edu/cq

23. Deborah Brunton (2014), Health And Wellness In the 19th Century, (Santa Barbara, California:Greenwood), 57
24. Michael Holstein (1988), "Writing as a Healing Art in Sarah Orne Jewett's The Country of the Pointed Firs", Studies in American Fiction, 16 no 1: 39-49. doi: 10.1353/ saf.1988.0031.

25. Swenson, Medical Women And Victorian Fiction, 47.

26. Josephine Donovan (1993), "Jewett and Swedenborg", American Literature, 65, no. 4 : j731-750. doi:10.2307/2927290

27. Sarah Orne Jewett (2008), The Country of the Pointed Firs, (Project Gutenberg, 2008) https://www.gutenberg.org/ebooks/19685

28. Ishita Chattopadhyay (2004), "Turmeric and curcumin: Biological actions and medicinal applications". Current Science 87 no. 1: 44-53; Claudia Daniele et al. (2005), "Vitex agnus castus", Drug Safety 28 no. 4: 319-332. doi:10.2165/00002018-20052804000004; Eric A. Apaydin et al. (2016), "A systematic review of St. John's Wort for major depressive disorder" Systematic Reviews 5 no. 1: 148. doi: 10.1186/s13643-0160325-2; R. A. Cooper et al. (2010), "Absence of bacterial resistance to medical-grade manuka honey." European Journal of Clinical Microbiology \& Infectious Diseases 29, no. 10 (2010), no. 10 : 1237-41. doi:10.1007/s10096-010-0992-

29. Jewett, The Country of the Pointed Firs, 25.

30. Sarah Orne Jewett (2008), The Queen's Twin, (Project Gutenberg).

31. Laurie Crumpacker (1983), "The Art of the Healer: Women in the Fiction of Sarah Orne Jewett", Colby Quarterly 19 no. 3: 155

32. Jewett, The Country of the Pointed Firs, 13, 37, 401.

33. Stanley W. Jackson (1994), "Catharsis And Abreaction In The History Of Psychological Healing", Psychiatric Clinics Of North America 17 no. 3: 471-491. PMID: 7824376.

34. Daniel J. Siegel (2007), The Mindful Brain: Reflection and Attunement in the Cultivation of Well-being, (New York:W.W. Norton), 68.

35. Daniel C. R. Chen et al. (2012), "Characterizing changes in student empathy throughout medical school" Med Teach. 34 no. 4: 305-11. doi: 10.3109/0142159X.2012.644600; Frans Derksen et al. (2015), "Empathy: what does it mean for GPs? A qualitative study." Family Practice 32, no. 1 (2015): 94-100. doi:10.1093/fampra/cmu080

36. Benoit Labonté et al. (2012), "Genome-wide epigenetic regulation by earlylife trauma", Archives of general psychiatry 69 no. 7: 722-731. doi:10.1001/ archgenpsychiatry.2011.2287; Rachel Yehuda et al. (2013), "Epigenetic biomarkers as predictors and correlates of symptom improvement following psychotherapy in combat veterans with PTSD." Frontiers in Psychiatry 4: 118. doi:10.3389/fpsyt.2013.00118

37. Jewett, A Country Doctor, 87

38. Farzad Goli and Carl Eduard Scheidt (2016), "Preface," "Some Reflections on Nonsubstance Bound Healing Effects and the Concept of Narrative Medicine." Biosemiotic Medicine (Springer International Publishing) v, 85-94.

39. Arden M. Morris et al. (2002), "Clostridium difficile Colitis, An Increasingly Aggressive latrogenic Disease?", Arch Surg 137 no. 10: 1096-1100. PMID: 12361411

40. Jewett, $A$ Country Doctor, 87

\section{BIBLIOGRAPHY}

Apaydin, Eric A, Alicia R. Maher, Roberta Shanman, Marika S. Booth, Jeremy N. V. Miles, Melony E. Sorbero, and Susanne Hempel. "A systematic review of St. Johns Wort for major depressive disorder." Systematic Reviews 5, no. 1 (2016), 148.

Armstrong, G. L, L. A. Conn, and R. W. Pinner. "Trends in infectious disease mortality in the United States during the 20th century." JAMA 281, no. 281 (1999): 61-6. PMID.

Blanchard, Paula. Sarah Orne Jewett: Her World and Her Work. Reading, Mass: AddisonWesley, 1994.

Breslaw, Elaine G. Lotions, Potions, Pills, And Magic: Health Care In Early America, 151-85. New York: NYU Press, 2012.

Brunton, Deborah. Health And Wellness In the 19th Century, 57. Santa Barbara, California: Greenwood, 2014.

Chattopadhyay, Ishitaet al. "Turmeric and curcumin: biological actions and medicinal applications." Current Science 87, no. 1 (2004): 44-53.

Chen, Daniel C. R, Daniel S. Kirshenbaum, Jun Yan, Elaine Kirshenbaum, Robert H. Aseltine DC Chen, J. Yan, and RH Aseltine. "Characterizing changes in student empathy throughout medical school." Medical Teacher 34, no. 4 (2012): 305-11.

Cooper, R. A, L. Jenkins, A. F. M. Henriques, R. S. Duggan, and N. F. Burton. "Absence of bacterial resistance to medical-grade manuka honey." European Journal of Clinical Microbiology \& Infectious Diseases 29, no. 10 (2010): 1237-41.

Crumpacker, Laurie. "The Art of the Healer: Women in the Fiction of Sarah Orne Jewett." Colby Quarterly, vol. 19, 3 ed, 155, 1983. http://digitalcommons.colby.edu/ca

Daniele, Claudia, Joanna Thompson Coon, Max H. Pittler, and Edzard Ernst. "Vitex agnus castus." Drug Safety 28, no. 4 (2005): 319-32.

Derksen, Frans, Jozien Bensing, Sascha Kuiper, Milou van Meerendonk, Antoine LagroJanssen, J. Bensing, F. Derksen, and S. Kuiper. "Empathy: what does it mean for GPs? A qualitative study." Family Practice 32, no. 1 (2015): 94-100.

Devine, Shauna. "To Make Something Out of the Dying in This War": The Civil War and the Rise of American Medical Science." The Journal of the Civil War Era 6, no. 2 (2016): $149-63$ 
Donovan, Josephine. "Jewett and Swedenborg." American Literature 65, no. 4 (1993): 731-50.

Eden, Ted. A Jewett pharmacopoeia, vol. 3, 4: Colby quarterly 28, 1992. http:// digitalcommons.colby.edu/cq

Goli, Farzad, and Carl Eduard Scheidt. Preface, "Some Reflections on Non-substance Bound Healing Effects and the Concept of Narrative Medicine. "Biosemiotic Medicine, 85-94: Springer International Publishing, 2016.

Holstein, Michael. Writing as a Healing Art in Sarah Orne Jewett's The Country of the Pointed Firs, vol. 16, 1 ed, 39-49: Studies in American Fiction, 1988.

Jackson, Stanley W. "Catharsis and abreaction in the history of psychological healing." Psychiatric Clinics of North America 17, no. 3 (1994): 471-91.

Jewett, Sarah Orne. The Foreigner, " A Country Doctor, The Country of the Pointed Firs, "The Foreigner," Novels and Stories. New York, Library of America, 1996.

. "The Queen's Twin": Project Gutenberg, 2008. https://www.gutenberg. org/ebooks/24822

. The Country of the Pointed Firs: Project Gutenberg, 2008. https://www. gutenberg.org/ebooks/19685

. A Country Doctor. New York: Bantam Classics, 2008.
Labonté, Benoit, Matt Suderman, Gilles Maussion, Luis Navaro, Volodymyr Yerko, lan Mahar, Alexandre Bureau., et al. "Genome-Wide epigenetic regulation by early-life trauma." Archives of General Psychiatry 69, no. 7 (2012): 722-31.

Levine, Deborah. "I Haven't Time to Write": Martha May Eliot and American Medical Education Reform." Annals of Internal Medicine 165, no. 10 (2016): 723-8.

Morris, Arden M, Blair A. Jobe, Mark Stoney, Brett C. Sheppard, Clifford W. Deveney, Karen E. Deveney, BA Jobe, CW Deveney. "Clostridium difficile colitis: an increasingly aggressive iatrogenic disease?" Archives of surgery 137, no. 10 (2002): 1096-100. PMID.

Numbers, R. L. "The history of American medicine: a field in ferment." Reviews in American History 10, no. 4 (1982): 245-63.

Siegel, Daniel J. The Mindful Brain: Reflection and Attunement in the Cultivation of Wellbeing, vol. 68. New York: W. Norton, 2007.

Swenson, Kristine. Medical Women And Victorian Fiction, vol. 9, 47. Columbia: University of Missouri Press, 2005.

Yehuda, Rachel, Nikolaos P. Daskalakis, Frank Desarnaud, louri Makotkine, Amy L. Lehrner, Erin Koch, Janine D. Flory., et al. "Epigenetic biomarkers as predictors and correlates of symptom improvement following psychotherapy in combat veterans with PTSD." Frontiers in Psychiatry 4 (2013): 118. 